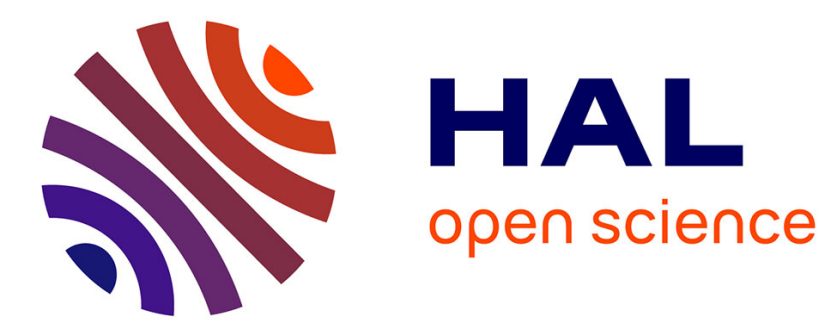

\title{
The Transnational Politics of the Ethiopian Muslim diaspora
}

Dereje Feyissa Dori

\section{To cite this version:}

Dereje Feyissa Dori. The Transnational Politics of the Ethiopian Muslim diaspora. Ethnic and Racial Studies, 2011, PP (PP), pp.1. 10.1080/01419870.2011.604130 . hal-00728416

\section{HAL Id: hal-00728416 https://hal.science/hal-00728416}

Submitted on 6 Sep 2012

HAL is a multi-disciplinary open access archive for the deposit and dissemination of scientific research documents, whether they are published or not. The documents may come from teaching and research institutions in France or abroad, or from public or private research centers.
L'archive ouverte pluridisciplinaire HAL, est destinée au dépôt et à la diffusion de documents scientifiques de niveau recherche, publiés ou non, émanant des établissements d'enseignement et de recherche français ou étrangers, des laboratoires publics ou privés. 


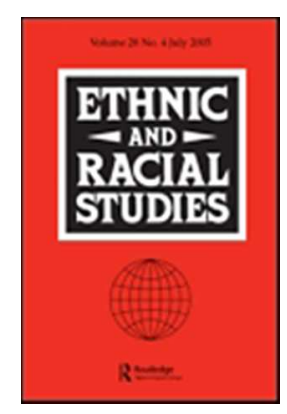

The Transnational Politics of the Ethiopian Muslim diaspora

\begin{tabular}{|r|l|}
\hline Journal: & Ethnic and Racial Studies \\
\hline Manuscript ID: & RERS-2010-0304.R3 \\
\hline Manuscript Type: & Original Manuscript \\
\hline Keywords: & $\begin{array}{l}\text { transnational politics of the diaspora, long-distance nationalism, diaspora } \\
\text { and peacebuilding, Islam in Ethiopia, The Ethiopian Muslim diaspora, } \\
\text { EPRDF }\end{array}$ \\
\hline
\end{tabular}

\section{SCHOLARONE ${ }^{\text {'M }}$}

Manuscripts 


\section{The Transnational Politics of the Ethiopian Muslim Diaspora}

1

2

3

4

5

6

10

11

12

13

14

16

17

18

19

20

21

22

23

24

25

26

27

28

29

30

31

32

33

34

35

36

37

38

39

40

41

42

43

44

45

46

47

48

49

50

51

52

53

54

55

56

57

58

59

60 


\section{Abstract}

Long distance nationalism is the dominant perspective in transnational studies. It depicts the diaspora primarily as 'conflict-makers' bent on advancing radical view points on homeland socio-political conflicts because of the unique decoupling of action from its consequences. Recent works have shifted the focus away from this negative image and have shown, through in-depth case studies, the constructive dimension of the transnational engagement of the diaspora. Two of these are the crucial role remittance plays in the development process in the country of origin and the peace building role of the diaspora in conflict and post conflict settings. The paper seeks to contribute to the diaspora-peace building literature through a case study of the Ethiopian Muslim diaspora in Europe and North America.

Key words - transnational politics of the diaspora; Long-distance nationalism; Islam in Ethiopia; the Ethiopian Muslim diaspora; diaspora and peace building; EPRDF 


\section{Introduction}

Ethiopia has one of the largest diaspora populations in the world. Although the exact number is yet to be known the government and some scholars estimate that more than two million Ethiopians live in the Middle East, Europe and North America (Lyons 2009). The paper examines the transnational politics of the Ethiopian Muslim diaspora in Europe and North America. Muslims despite them being the second largest religious group constituting $34 \%$ of Ethiopia's 80 million people, have been one of the country's historic minorities with a low level of political participation and a high degree of social discrimination by the country's dominant Christian elite. Although the political reforms since the 1974 revolution have to some extent redressed the issue of religious equality a lot remains to be desired before the Ethiopian national identity is reconstituted on a more inclusive basis. The paper argues that the Ethiopian Muslim diaspora, through rights based advocacy, are actively engaged in enhancing the wider game of democratic politics in Ethiopia. A closer examination of the tone of their rights advocacy and the symmetric collaboration between the diaspora and Muslims in Ethiopia also challenges the indiscriminate labeling of the diaspora as 'intransigent', 'hegemonic' and 'conflict actors', by the long distance nationalism framework in transnational studies.

The paper consists of five sections. Section one briefly reviews the literature on the nature of the transnational politics of the diaspora. Section two sets the homeland scene with background information of major religious groups and their relationship with the Ethiopian state in the longue duree. Section three provides an overview of the Ethiopian Muslim diaspora organizations; their transnational activities and the media they use to reach out to Muslims in Ethiopia, members of other religious groups, and the country's political leadership. Section four examines the discursive practices and direct involvement of the Ethiopian Muslim diaspora in their country of origin. The last part offers concluding remarks on the peace building dimension of the diaspora groups that challenges the negativity often attributed to diaspora within the framework of long distance nationalism.

\section{Diaspora and their Transnational Politics - a Review of Literature}

Four approaches are discernable from the literature of diaspora and their transnational politics. The first, and the most dominant, perspective is the conceptual framework of long-distance nationalism. Pioneered by Benedict Anderson (1992), long-distance nationalism depicts the 
diaspora as a particular form of subject bent on advancing radical view points on homeland socio-political conflicts. Accordingly, the intransigency of the diaspora emanate from the unique decoupling of action from its consequences. Located far in the comfort zone of the host countries the diaspora are supposed to indulge in radicalization of conflicts in their country of origin rather than working towards a negotiated settlement of social and political conflict. Examples of diaspora funding conflict in their home countries abound in the literature such as the behavior of the Serbian Diaspora before and during the Balkan wars (Blitz 1996) and the active involvement of the Tamil diaspora in the continuation of civil war in Sirilanka (Chalk 2008). Building on the works of Anderson, Demmers (2002:10) has recently noted, 'by long-distance interference with the conflict in their homeland, diaspora communities are engaged in a sort of virtual conflict: they live their conflicts through the internet, email, television, and telephone without direct (physical) suffering, risks, or accountability. Therefore, they are engaged in processes of conflict dynamics that differ importantly from their identity group members in their homelands'. Referring to the contribution of the diaspora to the 2005 post election violence in Ethiopia, Lyons (2009:589) also concurred with the general tenets of long distance nationalism: 'Diaspora groups created by conflict and sustained by traumatic memories tend to compromise less and therefore reinforce and exacerbate conflicts' protractedness [...] This tendency to frame the homeland conflict in categorical, hard-line terms strengthens confrontational homeland leaders and organizations and undermines others seeking compromise'.

Diasporas, like any other set of actors, can be simultaneously "peace-makers" and "peacebreakers". But much of the existing literature tends to concentrate on the negative aspects and influences exerted by diasporas on conflict situations (Pirkkalainen and Abdile 2009: 5). Responding to the criticism of the singular focus on the negative sides of the transnational diaspora politics more recent contributions argue that diaspora can also contribute positively to peace building processes by engaging in initiatives that either directly promote profitable dialogue processes or indirectly contribute to economic and social advancement, thus creating the grounds for sustainable peace (Warnecke 2010). Specifically, two positive dimensions of the diaspora have got attention in the recent works. One is remittance. The sheer magnitude of remittances sent by the diaspora to their country of origin has led many national, international and intergovernmental institutions to develop a commitment in this field by making it an explicit policy interest. The European Commission, for instance, has recognized diasporas as being 'actors of home country development' and identified a number of initiatives and recommendations to facilitate their direct involvement (EC 2005: 6). 
The importance of civil-society engagement in peace building in conflict and post conflictsettings is widely recognized (van Leeuwen 2009) and diasporas can rightfully play a role in such a position (Diaspeace 2010). This new perspective has positively signified what the long distance nationalism literature has considered the diaspora's structural barrier to peace building; the distance the diaspora have from the homeland: 'removed from the frontline of conflict, diasporas may have a wider and more objective perspective, less influenced by raw emotion and anger. In their new homeland, they may have access to a wider variety of information sources (Spear 2006: 7). As Newland (2004: VI) noted, 'given the degree of difference between Diasporas what is required is a thorough, country-specific understanding of Diasporas and the dynamics of their interaction with their country of origin'. Members of the Acholi Diaspora, for instance, have worked to bring together representatives from the Government of Uganda, the Government of Sudan, the Lords Resistance Army (the rebel group) and other groups with a stake in the conflict through a series of conferences designed to be open forums for dialogue between the parties, with the aim of promoting a negotiated solution to the conflict (Rigby 2006). As discussed by Zunzer (2004), members of the Afghan Diaspora have also played a constructive role in the 2001 "Petersburg Talks", convened by the United Nations and Germany which resulted in the formation of a transitional government for Afghanistan. The paper relates to the literature that recognizes the potential for and actual involvement of the diaspora in peace building. It does so through a case study of the Ethiopian Muslims diaspora in North America and Europe and their transnational politics in their country of origin.

\section{The Homeland Scene - Religious Groups vis a vis the Ethiopian State}

There are three major religious groups in Ethiopia: the followers of the Ethiopian Orthodox Church (EOC), Muslims, and Protestants (evangelical Christians). The origin of Orthodox Christianity in Ethiopian dates back to the $4^{\text {th }} \mathrm{AD}$ when King Ezana of the Axumite kingdom was converted into Christianity in 334 AD (Tadesse 1972). Orthodox Christianity had remained the official state religion in Ethiopia until the 1974 revolution. The Orthodox Church does not constitute a purely religious phenomenon in the country, but plays an integral role in all aspects of national life, including supplying many of the country's national symbols and core bases of political legitimacy. Although the EOC has largely lost its political leverage over the Ethiopian state and economic privileges after the 1974 revolution, it is nevertheless still the dominant religious group constituting, according to the 2007 census, 43 per cent of the country's population and the majority of the political elite. This dominant status is, 
however, currently contested by both Muslims and evangelical Christians. The EOC is very apprehensive of the rapid growth of Islam and Evangelical Christianity, which has generated a siege mentality.

Despite the strong identification of Ethiopia with (Orthodox) Christianity, Islam in Ethiopia is also as old as Islam itself. History of Islam in Ethiopia dates back to 615 A.D. when the companions of the Prophet Mohamed (the Sahaba) came to Axum fleeing religious persecution by the ruling elite in Mecca (Trimingham 1952; Erlich 1994). Muslim Sultanates were established in Ethiopia as early as the $9^{\text {th }}$ AD (Hussein 2006). During the medieval period there were various Islamic principalities in present-day southeastern part of Ethiopia which were gradually brought under the Christian kingdom. According to the 2007 census, Muslims constitute around 34 per cent of Ethiopia's population, which makes them the second largest religious group in the country. Historical longevity and large numerical size however starkly contrast with the profound socio-political marginalization of Muslims within the Ethiopian polity, where they were regarded as second class citizens at best and 'foreigners' at worst. Muslims in northern Ethiopia were not allowed to own land and they were as such forced to take up commerce and craftsmanship to make a living. Some Ethiopian Christian emperors had also sought to build a nation through political centralization and religious homogenization. These emperors in fact 'attempted to formally proscribe the practice of Islamic religion, endeavoring to enforce mass conversion to Christianity to enhance national unity' (Abbink 1998: 115).

The socio-political reforms brought by the 1974 revolution and the end of the Christian monarchy partly redressed the marginalization of Muslim within Ethiopian society (Hussein 2006). Church and state parted company and Ethiopia has been a secular state ever since. The religious reform of the military regime that replaced the Christian monarchy (the Derg), however, did not go to the extent of redefining the parameters of Ethiopia's national identity. Ethiopian historiography was left untouched with its 'unbroken' three thousand history paradigm; a historiography which is populated by Christian heroes and marginalizes the Islamic heritage of the country. The regime change in 1991 brought yet another opportunity to redress the issue of religious inequality in Ethiopia. The ruling Ethiopian People's Revolutionary Democratic Front (EPRDF) came to power as a champion of minority rights, though its attitude towards Muslims has changed over time. The 1995 Constitution generously provides for religious rights. Separation of State and Religion; freedom of religion, and freedom of association have encouraged the emergence of a confident and assertive Ethiopian 
Muslim community. Taking advantage of the freedom of movement, Ethiopian Muslims are now better connected with the wider Islamic World through Hajj and Umra, which were previously very restricted, as well as other forms of travel to Muslim countries (Carmichael 1997). Freedom of association has meant that Islam in Ethiopia, for the first time, has got a legal organizational expression. Religious equality is expressed in the construction of many mosques, though this has in some areas provoked strong Christian resistance and religious conflicts (Ostebo 2008). Liberalization of the press has also meant the emergence of Islamic publishing houses (Hussein 1998).

There is indeed an Islamic revival in Ethiopia since the 1991 regime change and the modest liberal opening henceforth. Nevertheless, there are still enduring constraints which Ethiopian Muslims face as a community in 'post-imperial' and 'post-socialist' Ethiopia. One of these enduring constraints is securitization of Islam by the members of the dominant Christian population and the EPRDF in the context of regional and global geo-politics. The EOC has viewed Islamic revivalism with consternation. It particularly feels threatened by the new historical and physical space Muslims have gained in post 1991 Ethiopia. One form of Christian resistance is discursive; labeling all aspects of Islamic revival in Ethiopia as if it were a manifestation of the so-called global Islamic fundamentalism. Similarly, Ethiopian governments across political regimes have all linked Islamic revivalism in Ethiopia with external players. The securitization of Islam in Ethiopia was at its height during the imperial period whose foreign policy making was heavily informed by religious considerations. In a speech before the United States Congress, Emperor Haile Selassie described his country as an island of Christianity in a sea of Islam. This myth was widely accepted abroad, and was propagated by the first generation of foreign scholars who studied this country (Markakis 2003:2). The ideology of Ethiopia as an Island of Christianity had produced a siege mentality; a country surrounded by belligerent Muslim Arab countries who are bent on destabilizing the Ethiopian polity for which Ethiopian Muslims might serve as 'fifth columnists' (Hussein 2006). This siege mentality had continued during the Derg period, though its secularist turn reduced the degree of securitization (Braukemper 2002).

EPRDF's securitization of Islam in Ethiopia has started since the mid-1990s. The growth of the Islamic Jihad in Eritrea (Miran 2005); the military confrontations between Al-Ithad - a Somali based Islamic group that actively operated in the Ogaden region - and the Ethiopian government (Medhane 2002), and the hostility between EPRDF and the National Islamic Front of Sudan in the mid-1990s (Erlich 2010) seems to have brought about a change in 
EPRDF's attitude towards Muslims. The main geo-political factor that has shaped EPRDF's policy towards Islam in Ethiopia is however the 'global war on terrorism' (Shinn 2004). Enthusiastically joining Bush's 'coalition of the willing', the Ethiopian government has sought to reposition itself and regain its strategic importance to the US led post-cold war global order. Adapting and reacting to this global discourse the EPRDF has managed to extract tremendous economic resources (development aid) and the much needed political legitimacy from the west despite its poor record on human right and political repression ${ }^{1}$. Ethiopia's invasion of Somalia in December 2006 against Somali Islamists (the Union of Islamic Courts) is situated within this larger geo-political context. This geopolitical consideration seems to have greatly shaped EPRDF's understanding of the complex Islamic reform movements primarily through a security lens. As Ostebo (2008:435) convincingly shown in his in-depth analysis of the dynamics of religious identification in contemporary Ethiopia, although Islam does not have a political agenda in Ethiopia the perception that it has informs government policy making: 'An increased number of mosques and higher representation of Muslims in public life can hardly qualify as evidence for a politicization of Islam in Ethiopia. It has not been uncommon, however, to equate Muslims demand for better representation with a politicization of Islam'.

Another enduring constraint to Muslims religious right in Ethiopia is the lack of a legitimate and functional organization. Islam had found no institutional expression in Ethiopia throughout the imperial period (Markakis 2006: 87). The first organizational expression dates back to the mid1970s. Linking up with the revolutionary fervour of the period hundreds of thousands of Ethiopian Muslims took to the street in Addis Ababa on April 20, 1974 claiming religious freedom and equality. The demonstrators also demanded the right to establish a nationwide organization that represents Muslims and enables them to run their own affairs and meaningfully participate in the affairs of the country. The Ethiopian Supreme Council for Islamic Affairs (widely known as the Mejlis) was formally established in 1976 'but throughout the period of military rule, it only functioned as a de facto, not dejure, organization' (Hussein 2006: 12). Moreover, there are indications that the Derg tended to view Islam and Ethiopian Muslims as a 'national security threat' especially in times of conflict with neighbouring countries which are predominantly Muslims (Braukemper 2002:4). The 1995 Constitution, on the other hand, has generously provided for religious freedom. Taking advantage of the constitutionally enshrined religious and associational rights, the Muslims reorganized the Mejlis; attained legal recognition, and a new leadership was elected. 
Besides, other types of Islamic associations proliferated such as the Ethiopian Muslim Youth Association, the Islamic Da’wa \& Knowledge Association and the Ulama Association.

The mid 1990s however brought government repression of Islamic organizations and the tighter control of the Mejlis. Following the 1995 'Mubarak incident', the attempt by the Egyptian Muslim Brotherhood to kill President Hussni Mubarek during his working visit in Addis Ababa, many Islamic associations and NGOs were closed down. Within the Mejlis itself power struggle led to a violent conflict between the police and the worshippers within the Anwar Mosque in Addis Ababa on February 21, 1995 in which nine people were killed and 129 people wounded (Abbink 1998). The EPRDF has tightly controlled the Mejlis leadership ever since with the pretext of avoiding similar incidents in the future. Over a period of a decade the Mejlis was represented by a leadership which suffered from a high popular legitimacy deficit. Under popular pressure the Mejlis elected new leaders in February 2009. Many Muslims are still skeptical about the new leadership, who they think was 'selected' by the EPRDF instead of assuming power through a competitive election.

\section{The Making of the Ethiopian Muslims diaspora}

The push factors for many of the Ethiopian diaspora are violent political conflicts since the 1970s. For others, international migration is the only means to improve their economic conditions. The preferred destinations of the Ethiopian migrants are Europe, North America and the Gulf countries. The diaspora has been actively involved in homeland affairs. It is the opposition parties' main constituency and the main source of finance (Lyons 2009). In recent years the government has also sought to create its own diaspora consistency. It has initiated a series of laws and directives to better 'govern' the structurally elusive diaspora, and tap into its financial resources for developmental purposes. Towards that end, the government established the General Directorate in Charge of Ethiopian Expatriate Affairs in 2002.

The paper focuses on the transnational politics of the Ethiopian Muslims in Europe and North America. The origin of the Ethiopian Muslims in the diaspora is part of the wider Ethiopian diaspora population which has been mobilized by the various political organizations at various times. Its religious mobilization is a recent phenomenon, which dates back to the late 1990s and has become vocal during and since the highly contested May 2005 election in which religious identity figured prominently in the rhetoric of the political parties that participated in the election. The rise of inter-faith conflicts in Ethiopia since 2006 has also led 
to the proliferation of Ethiopian Muslims diaspora organizations. These diaspora organizations were brought into two major umbrella organizations. The US-based BadrEthiopia was established in 2002 (hereafter Badr), and the Network of Ethiopian Muslims in Europe was established in 2004 (here after the Network). Badr and the Network advocate for the socio-political rights of Ethiopian Muslims which, in their perspective, is part of the wider agenda of reforming the Ethiopian polity. Failure to do so, reason these organizations, could well endanger the very survival of the nation.

Badr and the Network advocate for legislative and public policies for the protection of civil and humanitarian rights for Ethiopian Muslims by advancing the freedom of worship according to one's belief and the right of the people to assemble peaceably, and by petitioning the government for a redress of grievances. They also pursue open dialogues with the government and faith-based organizations with regards to protection of legal and constitutional rights, as well as pursuing intercultural and interfaith dialogues which can greatly contribute to mutual understanding, cooperation, and peaceful coexistence among the diverse peoples of Ethiopia. Badr and the Network have also sought to reach out to the Ethiopian Muslim population and the country's political leadership through various mechanisms. They have established a very strong cyber presence; issued statements on current socio-political events in Ethiopia; held demonstrations criticising government encroachments into religious rights; organized joint homeland-diaspora meetings; conducted Pal-talks and Tele-conferences, run online radio stations, and sent delegations to Ethiopia. In November 2010 Badr also launched a bi-weekly satellite TV program. Through all these media outlets the diaspora organisations have articulated the challenges Muslims face in contemporary Ethiopia. Apart from rights advocacy, they are also engaged in humanitarian activities such as support for education of orphans and children from poor families and projects dedicated to the prevention of HIV and support its victims at home. The heavyhandedness towards alternative Islamic organizations has left the diaspora as the only organized and autonomous Islamic voice who speaks for Muslims rights. In the following section I discuss at length three of the diaspora activities and their significance to and impact on homeland peace building. 


\section{The Transnational Politics of the Ethiopian Muslim diaspora}

\section{Setting an Agenda}

One of the novel modes of engagement of the Ethiopian Muslims in homeland affairs is sending delegations. The 2007 delegation is particularly noteworthy in setting an agenda for the Muslims' right movement in Ethiopia. This is significant because currently there is a crisis of organizational legitimacy of the Mejlis. The Mejlis has failed to articulate the legitimate demands of Muslims in contemporary Ethiopia such as the 2007 controversial census which is believed to have grossly underestimated the size of the Muslim population; the 2008 directive of the Ministry of Education that banned hijab and communal prayer in educational institutions, and infringement of Muslim citizenship right especially in the northern part of the country where the dominant Christian population, with the complicity of the regional governments, has blocked attempts by the Muslim minority to build mosques. In the absence of a legitimate organization the Muslims rights movement in the homeland is incoherent and the audience and the relevant actors - not least the Christian population - were at times in wont of explanation about the objectives of the rights movement. Others conflate Muslims demand for citizenship rights with a manifestation of 'Islamic fundamentalism' in Ethiopia. The agenda set by the diaspora on the other hand has an accent on religiously inclusive citizenship.

The April 2007 delegation consisted of nine members out of whom four came from the US; three from Europe, one from Canada, and one from Saudi Arabia ${ }^{2}$. The composition reflects the efforts the organizers made to represent the Ethiopian Muslims worldwide. Besides, all the nine members of the delegation have a high social standing consisting of religious and community leaders, scholars and known Muslims activist of equality, freedom and justice in Ethiopia. They are ethnically representative and theologically plural. Before the delegation headed for Ethiopia, it conducted a baseline survey in order to establish the prominent Muslim issues in contemporary Ethiopia. On the basis of its findings as well as the extensive feedback it got from Muslims in Ethiopia, the delegation produced a seventeen page document entitled Questions Raised by the Ethiopian Muslims diaspora to the Prime Minster Meles Zenawi, which outlined and articulated the prominent Ethiopian Muslims' issues (here after referred to as the Document). 
During its one month stay in Ethiopia the delegation, led by Mr. Nejib Mohammed, held discussion with high ranking government officials including the Prime Minister Meles Zenawi, and with a cross-section of the Muslim community and the Christian leadership. The document contains a wide range of issues, but the main talking points were: securing organisational autonomy of religious communities; implementing the constitutionally enshrined citizenship rights and religious equality; highlighting the Islamic heritage of the country; allowing the establishment of Islamic banks, and maintaining the secularism enshrined in the Constitution - in reference to the partisanship of the leadership of some of the regional states towards the Orthodox Church (e.g., in Tigray) and the Protestant Church (e.g., in Benishangul-Gumuz), and having a more balanced and responsible mass media. As the delegation noted, 'the discussion points are of particular interest to Muslims, they are nevertheless of great concern to all Ethiopians as they form the fundamentals to the country's peace, stability and prosperity'. The reference to this document by the various Ethiopian Muslim organizations, the Ethiopian government and in the counter-discourse of the Christian establishment makes it appear as the 'manifesto' of the emerging Ethiopian Muslims' rights movement. The main motif of this document and the recognition politics of the Ethiopian Muslims in general gears towards renegotiating the historic marginality of Muslims in the hitherto Christian dominated Ethiopian polity. Drawing on their new sets of democratic experiences in their host countries and referring to the globally recognized legitimizing discourses, the diaspora eschew the language of violence and frame their claims in the human rights language.

The rights-based advocacy of the diaspora sharply contrasts with some fringe elements within the Muslim community, which espouse violence against the Christian population and the Ethiopian government to enhance Islam's standing in the country with an ultimate objective of establishing an Islamic state. This approach, which defies Ethiopia's multi-cultural and multi-religious traditions, is certainly upheld, for instance, by the Takfir al Hijra, a splinter militant Islamic group from the Egyptian Muslim Brotherhood. Takfir operates in some parts of Ethiopia and is implicated in the 2006 religious violence between Christians and Muslims in the Jimma area (Zelalem 2009). Some scholars have conflated these fringe elements with the wider Islamic reform movement in Ethiopia. Haggai Erlich, for instance, has claimed that the Salafis (also called Wahabis) are working for the "political victory of Islam" (2007: 176) Ostebo (2010:31) refutes this assertion: 'Recognizing the country's religious plurality, Salafis position is that freedom and equality for the different groups could only be secured under a secular government. These - the few but vocal radical groups and their scholarly 
representation as if they were the dominant pattern - seem to have played a certain alarmist role in the securitization of Islam by the Ethiopian government, particularly in the new geopolitical context in which Ethiopia is considered by the west as one of the leading partners in the Global War on Terror (de Waal 2004). Against the backdrop of this complex nexus between radical religious groups, partisan scholarship and geopolitical interests, setting an agenda for Muslim citizenship rights by the diaspora is a welcome antidote.

The delegation was warmly welcomed by the Prime Minister but its mission was distorted by the state controlled mass-media as if it came to hold discussion with Ethiopian authorities about Millennium celebration ${ }^{3}$. EPRDF had celebrated the Ethiopian millennium in September 2008 with grand festivity partly to generate political legitimacy for a regime which is widely accused of by the opposition as 'unpatriotic' (Smidt 2007). Despite its misrepresentation the delegation held a series of meetings with various sections of the Muslim community explaining to them what they discussed with the political leadership and the need to jointly follow up the implementation of the promises made by the leadership. In one of these meetings more than one thousand attendants took part ${ }^{4}$.

\section{Re-constructing the nation on inclusive basis}

Many of the Ethiopian Muslims diaspora organizations have focused in their writing on deconstructing the image of Ethiopia as a Christian Island. They have reasoned that such representation is not only historically unfounded but also seriously undermines the process of state rebuilding and democratization of the Ethiopian polity. This discursive practice deconstructing the official Ethiopian history in order to make national reconstruction on an inclusive basis attainable - is focused on the Najashi narrative. The coming of the companions of Prophet Mohammed (sahaba) to Ethiopia in $615 \mathrm{AD}$ and the hospitality they received is a well established historical fact. What is contested is whether the Christian Axumite king embraced Islam or not. Various Arabic sources have documented Najashi's conversion to Islam, whereas many scholars of Ethiopian history (nearly all of them are Christians and western scholars) have ruled out the possibility of the king's conversion as 'implausible'. The main argument against Najashi's conversion is the absence of a major social upheaval that would naturally follow such a dramatic shift by a ruler of his religious affiliation. Countering that, Muslim scholars refer to Arabic sources that mention the existence of clerical opposition to Najashi's conversion (Hussein 1998; Ahmedin 2011). For these scholars and Muslim activists, the 'denial' is part of establishing the Christian hegemony in Ethiopia as if Ethiopia 
is destined to be ruled by Christian kings. Najashi's conversion to Islam is endorsed by the delegation and the Document is in fact imbued with the special place Ethiopia occupies in the history of Islam. The Network has also made the following commentary regarding the historical significance of the Najashi narrative:

\begin{abstract}
In Islamic history and tradition, Ethiopia is known as the "haven of the First Migration or Hijra". For Muslims, Ethiopia is synonymous with freedom from persecution and emancipation from fear. Ethiopia was a land where its king, Al-Najashi, was a person renowned for justice and in whose land human rights were cherished. The first migration of the Companions and relatives of the Prophet Muhammad to Ethiopia celebrates the birth of freedom of expression and beliefs, whereas, the Second migration of the prophet Muhammad to the medina celebrates the end of oppression ${ }^{5}$.
\end{abstract}

The Orthodox Church fiercely contests the Muslims' claim that the Christian king Armha who the Muslims call Najashi was converted to Islam. The Church in fact still claims the 'soul' of the Ethiopian nation on the basis of its intimacy with the state until the revolutionary rift between Church and State in 1974. Nearly four decades later, however, the nation's soul is still contested by its religious groups through various narratives of entitlement. For the followers of the Orthodox Church, Ethiopia is a 'chosen nation'. Accordingly, God transferred His grace from Israel to Ethiopia since the $10^{\text {th }} \mathrm{BC}$, evident in the transfer of the Ark of the Covenant from Zion to Axum and the establishment of the Ethiopian monarchy by Menelik I, the son of Ethiopia's Queen of Sheba and Israel's king Solomon (Brooks 1996). The followers of the Orthodox Church also produce evidence for the 'divine favor' by referring to the fact that Ethiopia is mentioned more than forty times in the bible (Ullendorf 1968). As Abbink (1998: 113) noted, 'due to its link with the "divinely ordained" Solomonic monarchy, Christianity inevitably was the core world-view of the political elite and a defining element of nationhood in a historical sense'.

While contesting the EOC's nativist claim and its presentation of other religious groups as mete (latecomers) many diaspora organizations have deconstructed such exclusive posture and produced their own counter narratives. As such, invoking the Najashi narrative is part of the Ethiopian Muslims' rights movement that centres on religious inclusion. This entails the redefinition of the parameters of Ethiopian national identity. The Najashi narrative thus addresses the issue of a secured sense of national belonging. Commenting on the new representation of Ethiopia propounded by the diaspora one of my Muslim interlocutors from Ethiopia said, 'it is for the first time that we Ethiopian Muslims started reconciling being 
Muslim and being Ethiopian. For our forefathers reconciling both sounded a contradiction in terms'. Tracing the history of Islam to king Najashi thus helps the Ethiopian Muslims to negotiate their 'foreignness'; a new foundation myth in reconstructing a national identity while it builds a new 'Great' tradition for Ethiopia as the land of the 'First Hijra'. The same narrative that refers to the strong Ethiopian component in early Islam also enables Ethiopian Muslims to claim a higher social status within the Ummah.

\title{
The call for autonomous community association
}

The issue of a legitimate and functional Islamic community organization is one of the most contentious issues between the EPRDF and the Muslims in the homeland and in the diaspora. Despite the growing discontent among the Muslims regarding the non-representativeness of the Mejlis the leadership has not sought to reach out the community and address the grievances. It is the diaspora delegation which for the first time had the courage to raise the issue of representative leadership with the Mejlis. Cognizant of the strong interference of the government in the affairs of the Mejlis the delegation also brought to the attention of Prime Minister Meles Zenawi, though the latter invoked secularism as an alibi. One of the leading issues which Muslims in the homeland and in the diaspora fully agree with is the question of the legitimacy of the Mejlis. In fact, the various diaspora organizations have highlighted the infringement of their right for an autonomous organization in different outlets. The following excerpt is from one of the postings by the Network:

\begin{abstract}
Among the fundamental rights Muslims denied off for centuries is the right to organize and establish institutions. One of the 13 demands raised during the 1966 Muslims demonstration was this basic right. To this date this demand is awaiting proper response. Worse, the sole institution that claims to represent Muslims and operates in their name has so far proved to rather working against Muslims themselves. It is now understood that the so called Islamic affairs councils from federal level down to Woreda are serving as peripherals of the security with the mission to suppress all forms of right claims by Muslims and pre-empt any such future aspirations ${ }^{6}$.
\end{abstract}

Muslims organizational demand has also the dimension of relative deprivation. This refers to the better organizational status of the Christian groups and government's complacency and desecuritization of their articulation with global Christian establishments; important factors in tipping the balance of power in inter-faith competition at the religious marketplace. While the Ethiopian Muslims freedom of association is curtailed the various Christian groups and 
associations are tolerated and in some instances have enjoyed government support. The document, for instance, refers to the use of public offices to promote sectarian religious interest by taking the example of the leadership of the Benishangul-Gumuz regional state. The fieldwork that I carried out in the region in 2009 as well as the web posting by the evangelicals corroborates the diaspora's claim of governmental partisanship. A born-again Christian, Yaregal Ayisheshim, the president of the region (1995-2009), has invited US based evangelicals to 'spread the Gospel' in the region. Whether this is part of a wider government strategy to change the religious demography of the region which has in recent times come under the influence of Islamists from the Sudan is difficult to ascertain. But geo-politics is not ruled out. Bordering the Sudan, the majority of the inhabitants of Benishangul-Gumuz, the Berta, are Muslims.

The delegation has also raised the issue of institutional imbalance by taking the example of the fewer Islamic NGOs which operate in the country in contrast with a wide variety of Christian NGOs. According to the Ministry of Foreign Affairs, there are 1,119 NGOs (978 local and 141 international) operating in the country. The Christian Relief and Development Association (CRDA) alone has 321 member organizations and the Ethiopian Orthodox on its part has more than 600 organizations. The number of Muslim organizations throughout the country, both local and international, however, is numbered in tens. Even the only well known relief organization, Ethiopian Muslims Relief and Development Association (EMRDA), operates under CRDA.

The Muslims' quest for a representative organization does not sit well with EPRDF's project of total control over society and the political process. Recent works have shown EPRDF's turn to authoritarianism especially after the contested May 205 election when the opposition put a formidable challenge (Clapham 2009; Aalen and Tronvoll 2009). Besides, EPRDF's led post-1991 political order in Ethiopia is built on an ethnic edifice. Although the Constitution has guaranteed religious freedom and equality it does not allow the political expression of religion. In fact, religious and other non-ethnic organizations have gradually and systematically been brought under control. The 2009 Civil Society Law (CSO) is providing a new legal framework which inhibits the growth and autonomy of the civil society. Although other religious groups and civil society organizations are also contesting the government's growing encroachments into civil liberties this has touched on the Muslims more than other religious groups because a representative and functional organization is one of the central factors in their quest for a national Islamic identity. Not only that the Mejlis has failed to 
evolve independently of the government it has also actively sought to block the emergence of alternative Muslim organizations. The diaspora's attempt to bridge the organizational gap is frustrated when they were denied in 2008 to open a liaison office in Addis Ababa despite the promise made to the delegation by the Prime Minister in 2007. The rejection was justified by the government in reference to the new CSO law according to which local NGOs which get more than 10 percent of their income from foreign sources and Ethiopian diaspora organizations licensed in a foreign country cannot engage in 'political domains' such as rights advocacy. The steadily narrowing of political and civil space in Ethiopia has disenchanted many diaspora groups who increasingly resort to a more confrontational stance and violent contestation of EPRDF's turn to authoritarianism (Aalen and Tronvoll 2009).

\section{Religious conflict resolution}

One of the enduring legacies of the delegation is the peace it brokered between the feuding ulama and the way it eased the simmering sectarian tension among the Ethiopian Muslims. At the time the delegation arrived in the country, the ulama were divided between 'the Sufi' (mystical Islam) and 'the Wahhabi' (scripturalist) camps, a tension which has resulted in some Muslim societies in violent conflict ${ }^{7}$. The significance of the delegation in diffusing this tension lies in creating a neutral forum to sort out theological differences peacefully. The delegation established a peace committee of 20 people - nine each from both camps and a neutral body consisting of two Muslim scholars from Addis Ababa University ${ }^{8}$. The two scholars were tasked to identify the contentious issues. They came up with 29 points of differences after an extensive public consultation. Both camps have recognized only nine issues as significant points of difference. These are related to the legitimacy of particular rituals and religious practices such as mawlid (whether or not to celebrate the Prophet's birth date), collective $d u^{\prime} a$ after a ja'ama salat (Friday prayer) and awliya (saint-veneration). The 18 people from both camps were asked to write position papers to explain and justify their respective stances on the contentious issues. The committee set binding rules for the debate, i.e., that all issues would be discussed within the framework of the four Islamic schools of thought. The discussion was held once in a week for three months and the membership was later on expanded to 35 people. This debating forum came to be known as the Addis Ababa Ulama Unity Forum (AUUF).

The AUUF managed to strike a compromise between the two camps on some of the contentious issues, and for the rest they have agreed to accommodate or tolerate their 
differences. Perhaps the greatest achievement of the AUUF is its moderating effect on the authenticity debate generated by the literalists and their scorn towards the Sufis. The AUUF managed to achieve that by historicizing the cultural embedment of the local Sufi practices. Credit was also given to the traditional ulama who relentlessly worked to rescue and nourish Islam in Ethiopia under unfavorable political circumstances. Both groups have also agreed to adopt a more gradualist approach in educating the public about legitimate Islamic practices than the radical approach espoused by the literalists. The AUUF also proposed structural reforms regarding Islamic education in Ethiopia such as establishing a Da'wa research centre that authenticate the capability of those who can engage in missionary activities; a new curriculum for the national Islamic study, and a grading scale for the graduates from local centers of Islamic learning.

The Mejlis leadership felt threatened by the growing public acceptance of the AUUF. It is no wonder, thus, that one of the first administrative measures taken by the new Mejlis leadership which came to power in February 2009 was to ban the AUUF and dismiss the leadership of the Addis Ababa Mejlis which had hosted the AUUF. Although the AUUF was subsequently abolished by the federal Mejlis, it had already set a model of conflict resolution. The Muslim community of Chagni area in the Amhara regional state, for instance, drew on the experience of the AUUF in resolving a conflict between the Sufis and the literalists ${ }^{9}$. By and large, therefore, the delegation has mollified the rising tension generated by the confrontation between the locally entrenched Sufis and the globally resourced Salafis, an encounter which has often resulted in violent confrontations elsewhere in the world.

The diaspora has also sought to dialogue with the leadership of other religious groups to foster tolerance and co-existence and resolve conflicts. Various scholars have noted the steadily increasing role of religion and inter-faith conflicts in defining the terms of political debate in Ethiopia, which has hitherto been dominated by ethnicity (Medhane 2003; Bahru 2008). Medhane (2003: 1), for instance wrote, 'the fault lines between religions will be the battle lines of the future in Ethiopia'. The 2006 religious violence between Christians and Muslims in Jimma, Illubabaor, Begi (Wollega) and Kemisse are indicative of the explosive nature of the underlying interfaith tension in the country. The diaspora leadership has noted on several occasions the need to establish an early warning system that diffuses the potential for conflict. In fact, one of the suggestions made by the delegation to the Ethiopian government was to establish a Ministry of Religious Affairs which could serve as a platform for the various religious groups to foster religious tolerance and work together on common national issues. 
Whether the establishment of the Directorate of Religious Affairs within the Ministry of Federal Affairs is the government implementation of the suggestion made by the delegation is hard to ascertain but at least government policy seems to have been influenced by it. Before heading to Ethiopia, the delegation had organized an inter-faith dialogue with church leaders in the diaspora. The delegation also visited hotspots of recent religious conflicts where they deliberated on the root causes of the conflicts and jointly reflected on ways to promote peaceful co-existence.

\section{Conclusion}

Various case studies have shown the peace building role diaspora groups could play in their country of origin. The Ethiopian Muslim diaspora in North America and Europe and their transnational politics fits into this category. The Ethiopian Muslim diaspora are actively engaged in public reasoning in the form of disclosing the continued existence of structures of religious inequality and seeking acknowledgement from the dominant Christian establishment and the Ethiopian government. This public discourse is an important asset to promote religious tolerance and peaceful-co-existence, for the alternative is to resort to other (violent) mechanisms of redress. As McClure (2006:8) noted, 'the driving back of certain types of claims outside the sphere of public reason encourages the creation of counter-publics devoted to social destabilization and fragmentation rather than to political reformation'.

Avoiding the victimology trap, the Ethiopian Muslims diaspora are not stuck on past injustices but are engaged in reforming contemporary Ethiopian society for a better future. This is important not only for the Muslim community at home, whose identity politics lack coherence and legitimate leadership, but also for reforming the Ethiopian polity at large. The use of the rights language in reference to the country's constitution and international conventions is also an important asset in the discursive struggle with fringe radical groups that have adopted the language of violence in the politics of recognition. This reflects the new pattern of juridification of protest at a global scale (Eckert 2006). 


\section{References}

Aalen, Lovise and Kjetil Tronvoll. 2009. 'The End of Democracy? Curtailing Political and Civil Rights in Ethiopia'. Review of African Political Economy No. 120:193-207.

Abbink, Jon. 1998. 'An Historical-Anthropological Approach to Islam in Ethiopia: Issues of Identity and Politics'. Journal of African Cultural Studies 11.2.

Ahmedin, Jebal. 2011. Ethiopian Muslims (615-1700): A History of Domination and Resistance. Addis Ababa: Najashi Publishers.

Anderson, Benedict. 1992. 'The New World Disorder'. New Left Review no.193.

Aqibaw, Yimer. 'Dilemma of Ethiopian Muslims amidst Mounting Right Abuses'. http://blog.ethiopianmuslims.net. Posted on April 20, 2009. Accessed on April 28, 2009.

Bahru, Zewde. 2008. 'The Challenge of the New Millennium: Renaissance or Reappraisal?' In Papers and Proceedings of Conferences on Fostering Shared Core National Values and Enhancing Religious Tolerance in Ethiopia in the New Millennium. Addis Ababa: InterAfrica Group

Blitz, Brad. (1996) ‘Serbia’s War Lobby: Diaspora Groups and Western Elites', in This Time

We Knew: Western Responses to Genocide in Bosnia. New York: New York University

Press.

Brooks, Miguel. 1996. A Modern Translation of the Kebra Nagast (The Glory of Kings). Red Sea Press.

Braukämper, Ulrich. 2002. Islamic History and Culture in Southern Ethiopia, Collected

Essays. Hamburg: Lit Verlag.

Chalk, Peter. 2008. 'The Tiger's Abroad: How the LTTE Diaspora Supports the Conflict in Sri Lanka'. Georgetown Journal of International Affairs.

Clapham, Christopher. 2009. 'Post-war Ethiopia: The Trajectories of Crisis'. Review of African Political Economy No. 120:181-192.

Carmichael, Tim 1997. 'Contemporary Ethiopian Discourse on Islamic History: The Politics of Historical Representation. Islam et societies su sud Sahara 10.

Demmers, Joell. 2002. 'Diaspora and Conflict: Locality, long-distance nationalism, and delocalization of conflict dynamics'. The Public 9 (1): 85 -96. 
De Waal, Alex 2004. Islamism and its Enemies in the Horn of Africa (ed.). London: Hurst \& Company.

DIASPEACE. 2010. 'Diasporas as partners in conflict resolution and peace building'. http://www.cespi.it/PDF/DIASPEACE policy paper.pdf

Eckert, Julia. 2006: 'From Subjects to Citizens: Legalism from Below and the Homogenization of the Legal Sphere'. Journal of Legal Pluralism (53-54): 45-75.

Erlich, Haggai. 2010. Islam and Christianity in the Horn of Africa: Somalia, Ethiopia, Sudan. London: Lynne Riener Publishers.

-2007. Saudi Arabia and Ethiopia: Islam, Christianity and Politics Entwined. Boulder \& London: Lynne Rienner Publishers.

EC. 2005. 'Migration and Development: some concrete orientations." Communication from the Commission. Brussels, European Commission. http://eur-lex.europa.eu/LexUriServ/

Hussein, Ahmed. 1998. 'Islamic Literature and religious Revival in Ethiopia (1991-1994)'. Islam et societies au sud du Sahara 12.

---------------2006. 'Co-existence and/or Confrontation: Towards a Reappraisal of ChristianMuslim Encounter in Contemporary Ethiopia'. Journal of Religion in Africa 36 (1).

Lyons, Terence. 2009. 'The Ethiopian Diaspora and Homeland Conflict'. In: Proceedings of the 16th International Conference of Ethiopian Studies, ed. by Svein Ege, Harald, Aspen, Birhanu Teferra and Shiferaw Bekele, Trondheim, pp.589-599.

Markakis, J. 2006. Anatomy of a Traditional Polity. Addis Ababa: Shama Books.

Mclure, John. 'The Politics of Recognition at an Impasse? Identity Politics and Democratic Citizenship'. Canadian Journal of Political Sciences. 2003 (36): 3-21.

Medhane, Tadesse. 2003. 'Religion, Peace and the Future of Ethiopia'. Paper presented at the $1^{\text {st }}$ national Conference on Federalism, Conflict and Peace building, May 5-7, 2003, Addis Ababa.

------------2002. Al-Itthiad: Political Islam and Black Economy in Somalia: Religion, Money, Clan and the Struggle for Supremacy Over Somalia. Addis Ababa: Mega Publishers.

Miran, Jonathan. 2005. 'A Historical Overview of Islam in Eritrea'. Die Welt des Islams, 45 (2): $177-215$.

Ostebo, Terje. 2010. 'Islamism in the Horn of Africa: Assessing Ideologies, Actors and Objectives'. ILPI Report. 
---2008. 'The Question of Becoming: Islamic Reform Movement in Contemporary Ethiopia'. Journal of Religion in Africa 38:416-446.

Pirkkalainen, Päivi, and Mahdi Abdile. 2009. 'The Diaspora - Conflict - Peace - Nexus: A Literature Review'. DIASPEACE Working Paper 1.

Spear, Joanna. 2006. The potential of Diaspora Groups to contribute to Peace Building: A Scoping Paper. http://www.brad.ac.uk/acad/twe/publications/working_papers/Spear.

Tadesse, Tamirat. 1972. Church and State in Ethiopia, 1270-1527. Oxford.

Questions Raised by the Ethiopian Muslims diaspora to the Prime Minster Meles Zenawi (April 2007)

Shinn, David. 2004. Fighting Terrorism in east Africa and the Horn. Foreign Service Journal. http://elliott.gwu.edu/assets/docs/research/Shinn.pdf

Smidt, Wolbert. (2007), Introduction, in: W. Smidt and K. Abraham (eds.), Discussing

Conflicts in Ethiopia, Wien: LIT.

Trimingam, John. 1952. Islam in Ethiopia. London.

Ullendorf, Edward. 1968. Ethiopia and the Bible. London: The Oxford University Press.

van Leeuwen, Mathijs. 2009. Partners in Peace. Discourses and Practices of Civil-Society Peacebuilding. Aldershot, Ashgate.

Warnecke, Andrea. 2010. Diasporas and Peace: A Comparative Assessment of Somali and Ethiopian communities in Europe. DIASPEACE Working Paper 2.

Zelalem Temesgen. 2010. 'The 2006 Religious Conflict in Didessa and Gomma Waradas of Western Oromia'. Master-thesis in Ethiopian Studies: Addis Ababa University.

Zunzer, Wolfram. 2004. Diaspora Communities and Civil Conflict Transformation. Berghof Occasional Paper no. 26. Berlin: Berghof Research Centre for Constructive Conflict Management.

DEREJE FEYISSA is a fellow of the Alexander Von Humboldt for experienced researchers at the University of Bayreuth

ADDRESS: Department of Anthropology, University of Bayreuth, Facheinheit Ethnologie, GWII Universitätsstr. 30, 95445 Bayreuth. 


\footnotetext{
${ }^{1}$ See HRW. 2010. Development without Freedom. How Aid Underwrites Repression in Ethiopia.

${ }^{2}$ These are Akimel Shamil, Mansur Muhammad, Nejib Mohammed and Dr. Zeki Sheriff from the USA; Abiye Yasin from Belgium; Muhammad Hassan from Germany, Abdulla Hassan from Sweden, Sheikh Mohammed Awel from Canada, and Dr. Abdul Jelil from Saudi Arabia.

${ }^{3}$ Ethiopian News Agency, April 8, 2007.

${ }^{4}$ The delegation of Ethiopian Muslim diaspora, VCD, April 2007

5 Najib Mohammed, The Haven of the First Hijra: An African nation is the Muslims' first refuge, (http://www.ethiopianmuslims.net/Islam_in_Ethiopia/African\%25Nation.htm).

6 Aqibaw Yimer. 'Dilemma of Ethiopian Muslims amidst Mounting Right Abuses. http://blog.ethiopianmuslims.net. Posted on April 20, 2009. Accessed on April 28, 2009.

${ }^{7}$ The Sufi camp was led by Haji Omer, the Mufti of Addis Ababa and the Wahabi camp by Dr Jeylan.

${ }^{8}$ These were Dr Idris Mohammed and Hassen Taju.

${ }^{9}$ Interview with Hassan Taju, facilitator of the AUUF, Addis Ababa, November 12, 2009.
} 